\title{
Telling the Nation: A Postmodernist Reading of Tanure Ojaide's God's Medicine-Men and Other Stories
}

\author{
Henri Oripeloye \\ Department of English, Obafemi Awolowo University, Ile-Ife, Nigeria \\ Email: henrioripeloye@yahoo.com
}

Received 25 July 2014; revised 5 August 2014; accepted 28 September 2014

Copyright (C) 2014 by author and Scientific Research Publishing Inc.

This work is licensed under the Creative Commons Attribution International License (CC BY). http://creativecommons.org/licenses/by/4.0/

(c) (i) Open Access

\begin{abstract}
Postmodernist reasoning signifies a move from traditional viewpoint to an accelerated technological terrain, the implication of this diversion is noticeable in the eclectic nature of life in contemporary society; all things become a continual flickering without any recognizable or perpetual presence. As a literary concept, postmodernism fashions the problematic landscape for the appreciation of the disordered nature of the world as it focuses on the dismantling of traditional values and affirmation of a fragmented society. Postmodernism, with its subtle emphasis on capitalism, has greatly exacerbated the post-colonial tendencies in Tanure Ojaide's God's Medicine-Men and other Stories as money becomes a recurrent motif and a chief signifier. The stories underpin the overarching effect of cultural materialism, individuals and the society as everyone is caught in its web; these stories could also be read as the author's depiction of a society that is going through a cultural flux.
\end{abstract}

\section{Keywords}

Postmodernism, Cultural Values, Nation, Short Stories, Tanure Ojaide

\section{Introduction}

Writings in modern societies are influenced by the events that shape the consciousness of the people and the historical antecedents that have contributed to these changes. As a site of literary production, the environment informs the mode of artistic creativity in these societies; hence writers use their work to explain the social, political, economic and cultural problems that are prevalent in the society. Interestingly, these writers are aware of the external influences that are affecting people's way of perception and attitudes within the society. Postmod- 
ernist cultural tendency is one of these negative influences as it signifies a move from traditional viewpoint to an accelerated technological terrain through its subtle emphasis on capitalism.

The postmodern as described by Frank Davey is “an international movement, elitist, imperialist, 'totalizing' willing to appropriate the local while being condescending toward its practice” (Davey, 1988: p. 119). Davey implies that postmodern culture takes cognizance of traditional cultural forms but rejects its place in the formation of modern social and political tropes of identity. In postmodernist discourse what operates is a perverted human consciousness that is constantly modifying the contemporary society out of its value systems. In these societies, man becomes an inconsequential fragment or an inexplicable object as money dominates the consciousness of the people. We are witnessing a peculiar condition in which all the traces of traditionalism are being swept off to create room for an outright obsession with capitalism. Postmodernism favors the fragmentation of the society as it opens the world to an inescapable technological force that undermines the positive influence of cultural values. More important, postmodernism in its attenuation of cultural values is influenced by a complex system through the depiction of a new social consciousness that sets aside the primacy of communality; hence it is depicted "as a retheorization of the proliferation of distinctions that reflect the underlying dynamic of cultural modernity" (Appiah, 1996: p. 61). In all possibilities, postmodernism works towards the ossification of cultural essence of a society. Uche Mowah points out the negative effects of this term when he describes postmodernism as "an instrument of promoting the devastating demolition of salutary norms and values by the caterpillar wheels of capitalism" (Mowah, 2004: p. 68). Social norms that are regarded as revitalizing force within a society are jettisoned in postmodernist thought and this signifies a movement away from cultural mores, hence the appropriation of negative signifiers within the society.

Postmodernism underpins the post-colonial discourse from various angles but in this paper, we are considering the logic of late capitalism, a culture that Fredric Jameson describes as a radical split between the private and public and between the world of classes of economic and of secular political power (see Ahmad, 1994: p. 108). This cultural disruption envisaged by Jameson is represented in literature that reflects the changes in the authentic African. As a capitalist mediated discourse, money becomes the major factor in the obnoxious reinvention of societal values and the consequent rupturing effect it produces. African writers are concerned with the deracinating effect of alien values within the society, they perceive this in historical, socio-cultural and political experiences that are central to the cognitive formation of individual characters in the society, but of much concern is the erosion of traditional values in the face of competition with modernization. This has caused the dichotomization of values resulting in apprehension as the society acquires warped set of values that are constantly in confrontation with traditional values. This is a major cause of the postcolonial tensions that are rampant in these "new" societies because modernization opens the world to a catastrophe of unimaginable propensity. Postmodernism as a literary construct should as a matter of objectivity activate the essentialness of traditional values while admonishing a further shift in the entrenchment of its idiosyncrasies within an alien environment. But instead of assuaging these problems, postmodernism has exacerbated the depletion of socio-cultural attachment in African societies. It has brought tensions between an individual and his innate ability to survive as demonstrated in the severance of relations between traditional values and modernity. Sangari Kumkum underscores this analogy when he claims that "not only has the destabilizing of the image that modernism effected now been extended into the prose of postmodernism critical theory and refined anew, but a postmodern aesthetic continues to raid the 'inarticulate' cultural forms of 'Third World' to 'textualize' a geographically or culturally lost terrain" (emphasis mine) (Sangari, 1995: p. 145).

A new attitude towards the Nigerian experience has been the focus of literature in recent years, there is a new apprehension of events, of social and economic forces as they interact to create the sense of a volatile nation. This reveals a pattern of relation to an emerging postcolonial condition and the will on the part of the writer to inscribe this experience within the fabric of modern society. This new way of expression reflects the mood of disillusionment and of escaping morality within the system. The literature projects a negative apprehension of the Nigerian nation in its entire somberness and gloom as Abiola Irele affirms when he says that "at a deeper level of moral awareness, the new stance of the African writer as it comes through in the majority of novels dealing with the postcolonial situation contains within it and carries with it a natural skepticism in the face of human affairs” (Irele, 1981: p. 71). It is against the foregoing background that this paper examines the negative aspects of postmodernism in the Nigerian nation as exemplified in Tanure Ojaide's God's Medicine-Men and Other Stories (Ojaide, 2004). Tanure Ojaide, a poet, novelist and literary critic is grouped among the generation of Nigerian writers whose ideological bent is located within the prism of cultural, social and political emancipa- 
tion of the masses. He has authored over ten collections of poetry and a number of short stories; he is among the best known writer from Africa. He has won many awards for his literary effort, such as the Commonwealth poetry prize (1987) and the BBC Arts and Africa poetry award (1988).

The study is informed by the disappearance of pristine alliance in the stories in God's Medicine-Men and Other Stories as urban structure of the stories opens itself to dubious modernity and the discovery of a cultural interpretation that stultifies both the people and the community. Tanure Ojaide demonstrates that traditional African societies and cultures no longer exist in this age and in keeping with his postmodernist temper, the modes of utterance, terminologies and concepts in God's Medicine-Men and Other Stories are predominantly cosmopolitan and most of the characters engage in modern professions and economic pursuits. The stories become a testament for the encoding of the prevailing condition in Nigeria. Within the society, there is a pull towards disintegration by virtue of its hostile or fragmented nature that results in the discovery of a society with "no moral certainties, no social stability, no authentic cultural values, no definite sense of reality” (Uledi-Kamanga, 1999: p. 32).

Ojaide presents a vision of a nation that is dominated by angst and man at the mercy of incomprehensible terrors as he responds to the magnitude of horrors that destroy the authentic African life and culture as they are being adulterated by foreign influence. He is concerned with the explorations of the place and the value of the indigenous culture in Nigeria while using his "delta" narratives as a platform. Affectation, lust, greed and forms of mischief are construed as mad attack on traditional African values and family relationships; it also marks the dreariness of life under capitalism. Most of the characters in God's Medicine-Men and Other Stories are representative or at best allegorical ones. Ojaide uses these characters to construct the problems of a nation that is going through a flux of arbitrariness in the perception of reality. Through these characters, he demonstrates how the pursuit of success and achievement can negatively affect the development of the individual and that of his society. This becomes clearer when great expectations produce great tragic consequences in the lives of the heroes and that of the community. The stories demonstrate how the postcolonial condition has reduced the people to passive victims of postmodernist ethos as the characters reveal an alien symphony of crisis that has severed them from their past and cultures. Beyond the façade of the events we witness in these narratives- the social and human problems in a fleeting society - there is an all embracing moral implication that Ojaide reveals to his sensitive readers; and this is that, a society that drifts holistically towards modernity heads for an inevitable disaster.

\section{Textual Analysis}

"God's Medicine-Men”, the title story sets the mood for the postmodernist ambivalence in contemporary Nigerian society as depicted in the eclectic nature of the characters in this story. Their spiritual attachment reveals the fluidity of belief system in a new African society. As a pastor and bishop, Odele and Efe are the custodians of societal morality in Christian ways but in reality, they are charlatans who cannot survive as adherents of Christian faith. So, they assume dual personalities-one is the open acceptance of Christ and the other is the secret romance with olokun. That pastor Odele combines the cult of olokun with his Christian faith attests to the religious syncretism in the society explored in God's Medicine-Men and Other Stories. In the same way, Endurance's attempt to solve a spiritual problem in an orthodox manner befuddles a reader with an African consciousness. After she has tried in vain to ward off the intruder that steals sex from her every night in her sleep, she believes that taking contraceptives is a way out of the problem, according to the writer, "she thought seriously of buying contraceptives from one of the many pharmacists in the town. She had to protect therself...” (p. 74). This reasoning reveals the paradox of existence in a postmodernist age where spiritual matter is conceived in its ordinariness rather than the seriousness that is attached to it in a traditional society. It is only when the matter is approached in a realistic African way that Endurance begins to have a way out of the problem.

"The last-born" is a story that depicts the effects of postmodern thought in terms of social relations. Dr. Ubi and Titi are engrossed in a relationship that survives on lies. As husband and wife, in a traditional setting, all secrets (past and present) must be shared, but in a society that is opened to modernity, the survival of a marriage is premised on how one can efficiently deceive the other. In this story, the mother-daughter relationship that turns to be sister relationship enables Titito fulfill her desire in marriage. In spite of the physiological resemblance between Tetebe and Eloho, his own daughter, Dr. Ubi is in the dark to the past life of his wife. To cover the past, Titi devices various means-switching off the lights before lovemaking with her brazier on is a gimmick to 
confound the unsuspecting husband about the events of her past life. In a traditional society, the epiphanic revelation that Tetebe is Titi's daughter is capable of shattering the marriage but this catastrophe is tempered by the characters' postmodernist view of not seeing anything wrong in mothering or fathering a child before marriage. The palpable intensity of the postmodernist world of this story is captured when a purely love/social relation is perceived from a materialistic dimension. When Dr. Ubi and Titi got married, people see the union as a form of money making machine instead of the pure love relations. With the marriage, the couple is believed to be rich as the couple would establish their own hospital where they would make millions of naira. This attachment to materialism is expressed in the manner of postmodernist pastiche:

That man and woman would not smell want in their lives again... In Warri, without money you were nothing. The rich were seen as naturally enjoying, and the poor suffering. A marriage that brought man and woman together to enhance their money-making capabilities was the ideal in the material view that pervaded the oil city (pp. 18-19).

What happens in the case of Dr. Ubi and Titi clearly reflects the situation in postmodernist society where there is an implicit disordering in human relations.

"I Used to drive a Mercedes" projects the nothingness of the world. Life is meaningless and man is presented as the doomed specie as all efforts made by man to overcome the vagaries of life meet with failure. Alfred's self inflation is an essential postmodernist phenomenon as individual seeks personal goals and achievements which eventually lead to disaster. His life is encapsulated within the problematic of social and economic relations where madness becomes a saving grace for the oppressed. He is a symbolic articulation of the annihilating power of the postcolonial condition. Alfred's drift to madness is perhaps not an accident; it is a culmination of the absurdities that characterized the society he finds himself. The tragedy does not arise primarily from the hubris in his person but much more as a consequence of the inexplicable social economic forces militating against the individual in a society that is embracing new form of values. Sarah, his wife is a woman that is susceptible to modern ways of life. Her exposure leads to her romance with Alhaji Isa and as a modern woman, she unashamedly prides in her sexual escapades with Alhaji thus: "If I had not got Isa, one of them would have stolen the golden man for herself... She went to war with them and she has been victorious” (p. 59). Her request that Alfred should take her to a hotel to pass the weekend instead of staying at home derives from her new experience. She calls Alfred "Major for nothing" and taunts him with statement like "see your mates with Mercedes for their wives while I am still on footer on and you driving a Beetle” (pp. 60-61). She eventually abandoned Alfred for a man that has a mercedes. Ironically, Alfred's move to satisfy these modern expectations of his wife destroys him:

He was going to buy a Mercedes. Let Sarah see him driving a Mercedes and come back to him. He felt buying a Mercedes was the charm that would reverse his failed marriage into a fresh love (p. 62).

Alfred's effort to meet the material demand of his time leads him to sell his poultry farm, a farm that has become part of his being. This reveals that money is an alternative to transcendental value in postmodernist society. The eventual tragedy that struck him is a demonstration of the enigmatic relations and chaos in contemporary Nigerian society. The story of Alfred provokes both pity and condemnation for the society that produces such a failed character.

In "The Roadblock”, Ojaide recreates the reality of existence in Nigeria. Illegal police checkpoints, accidental killings and cover-up are commonplace in the Nigerian system. There is a macabre touch in this story when the policemen kill their boss for challenging their authority for mounting an illegal roadblock. The Nigerian flavor in the story is further engrained in the activities of Debo Fakade, the prison superintendent whose duty is to keep the policemen while awaiting trial. As in the other stories money is at the centre of the action here. From private Oyibo to Mr. Debo Fakade, the prison superintendent and the court judge, Mr. Isaiah Okitikpi, money becomes the motivating factor for their actions and inactions. Ojaide through these crooked characters presents a cesspool of bribery and corruption that is at variance with national development. Also in 'The Book case' Ojaide explores the cynicism of existence. Human activities are rendered impotent and meaningless. A peculiar challenge of life is that man is a solitary being and that individual affiliation is superficial and perhaps an accident that could only produce negative results. It is in this light that one understands the fatal fate of Mrs. Fatumbi, the brilliant teacher whose aim of improving the standard of education in her society failed woefully because of her association with Dede Daro the stigmatized journalist. 
The soul-lessness of modern society is the central motif of “The Wake-keeping”. Odovia's children have bastardized traditional norms and mores when they could not claim the corpse of their father for burial from the mortuary. Funeral ceremony in Nigeria is very interesting as there are series of activities associated with it. But in this story, the children of the deceased failed in their filial responsibilities, as they could not afford the money to reclaim the corpse from the morgue. Rather than show remorse for their inaction, the children remain passive as if nothing is amiss, an action that portrays their postmodernist disposition. A sardonic humor is added to the event when the people present tacitly agree that the clinic could burn the corpse if the children are unable to recover the body. This is instructive, as it shows that anything can happen in a postmodernist society where there is a perversion of the normal social code.

\section{Conclusion}

The stories in God's Medicine-Men and Other Stories provide an explanation for the eclectic pattern of life in a postmodern society. Latent in all these stories is the enigmatic relations of people that shape the contemporary Nigerian society. This is presented as a fictional transposition and interrogation of the endemic influence of money in terms of the tension that it generates among individuals. Through the metaphor of death, distrust and disillusionment, the stories reveal the disruptive effect of icons of modernity on Ojaide's traditional homeland in the Delta and by extension the Nigerian nation. In essence, this essay shows that postmodernism with its subtle emphasis on capitalism has greatly exacerbated the postcolonial tendencies in Tanure Ojaide's God's MedicineMen and Other Stories as money becomes a recurrent motif and a chief signifier. Its presence or absence directs most of the actions in these stories, and thus the stories could be understood within the context of capitalist drive towards materialism which depicts a roaring world where everyone listens to his own voice and as a symbolic construct, marks Ojaide's stories as forms of uncertainties in a postmodern world.

\section{References}

Ahmad, A. (1994). In theory: Classes, Nation Literatures. London and New York: Verso.

Appiah, K. A. (1996). Is the Post-In Postmodernism the Post-In Postcolonial. In M. Padmini (Ed.), Contemporary Postcolonial Theory (pp. 55-71). London: Arnold.

Davey, F. (1988). Reading Canada. Winnipeg: Turnstone.

Irele, A. (1981). Parables of the African Condition: A Comparative Study of three Post-Colonial African Novels. Journal of Comparative Literature, 1, 69-91.

Mowah, U. (2004). Liberation Narrative and Post-Modern Africa. In O. Onookome (Ed.), Ogun's Children (pp. 67-80). Eritrea \& Trenton: Africa World Press.

Ojaide, T. (2004). God's Medicine-Men and Other Stories. Lagos: Malthouse.

Sangari, K. (1995). The Politics of the Possible. In A. Bill et al. (Eds.), The Post-Colonial Studies Reader (pp. 143-147). London and New York: Routledge.

Uledi-Kamanga, B. (1999). Exile and Alienation in Paul Tiyambe Zelaza's Thejoys of Exile. Journal of Humanities, 13, 26-46. 
Scientific Research Publishing (SCIRP) is one of the largest Open Access journal publishers. It is currently publishing more than 200 open access, online, peer-reviewed journals covering a wide range of academic disciplines. SCIRP serves the worldwide academic communities and contributes to the progress and application of science with its publication.

Other selected journals from SCIRP are listed as below. Submit your manuscript to us via either submit@scirp.org or Online Submission Portal.
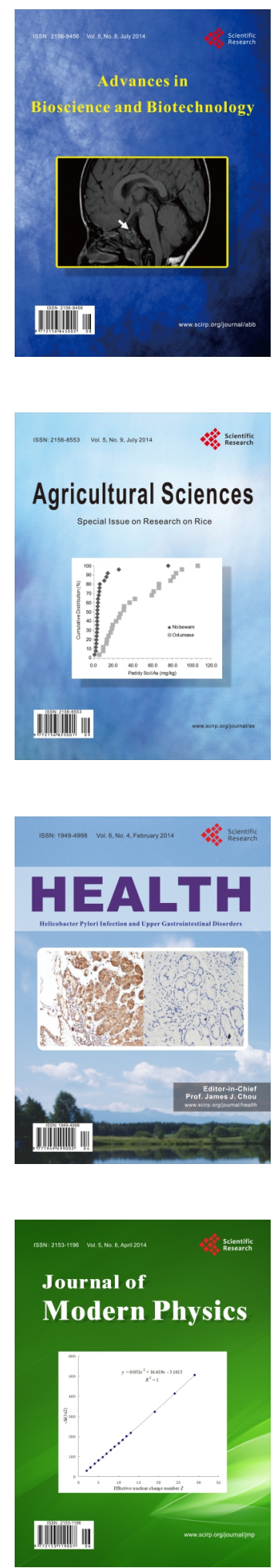
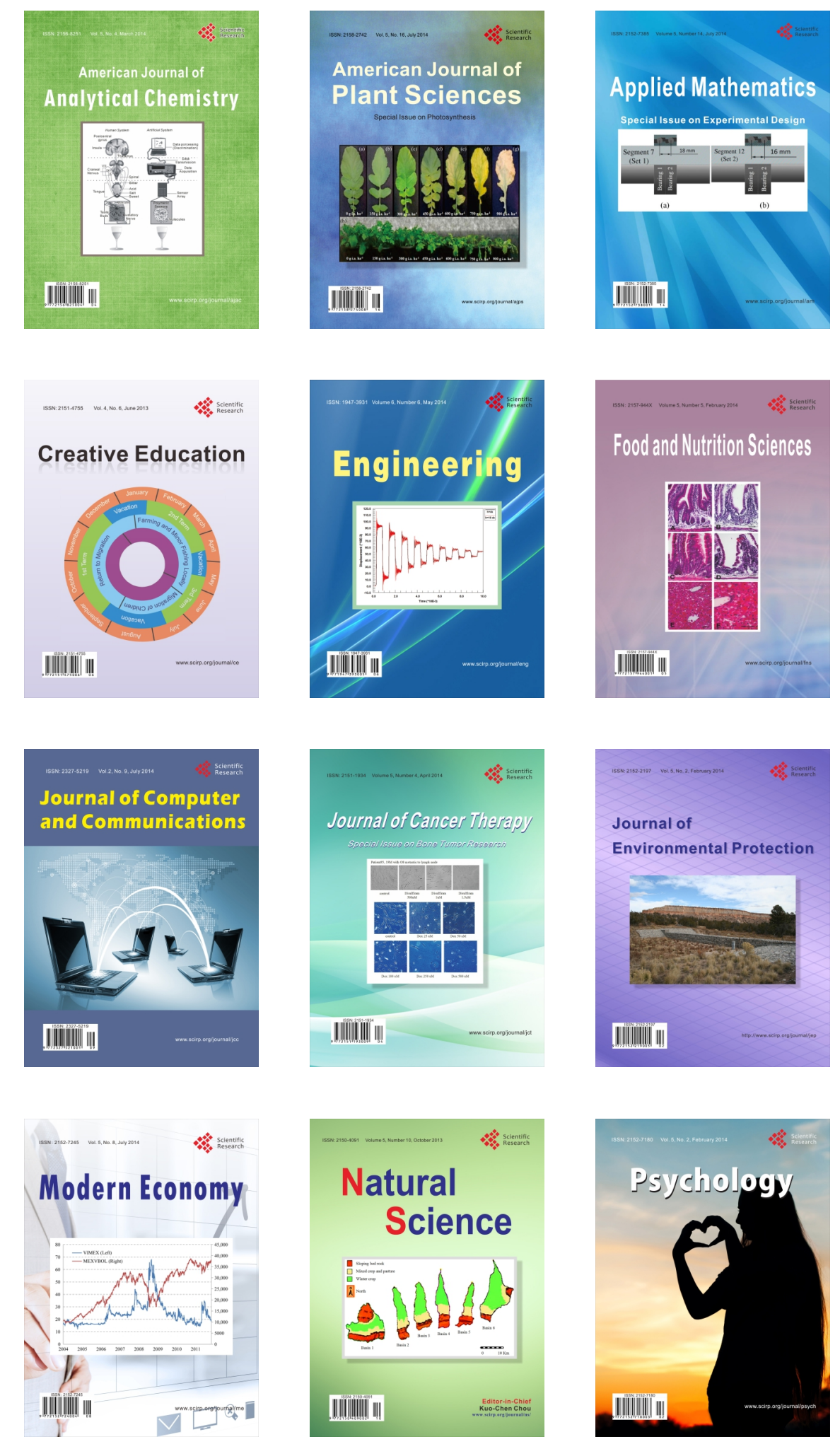